\title{
Improved breeding success of Great- winged Petrels Pterodroma macroptera following control of feral cats Felis catus at subantarctic Marion Island
}

\author{
JOHN COOPER and ANDRE FOURIE
}

\section{Summary}

A population of feral domestic cats Felis catus has existed at subantarctic Marion Island since 1951. From 1977 to 1990 an ongoing programme has utilized an introduced disease, shooting and gin-trapping in an endeavour to control cat numbers, with the eventual aim of their eradication. Burrowing petrels (Procellariidae) form the majority of the cats' diet. The breeding success of the winter-breeding Great-winged Petrel Pterodroma macroptera has varied between nil and $20.5 \%$ in the period from 1979 to 1984 , due primarily to cat predation of chicks causing up to $100 \%$ mortality. In 1990, by which time cat numbers had been greatly reduced from their 1970s' peak, Great-winged Petrels had a breeding success of $59.6 \%$, with chick mortality being zero. No signs of cat predation were observed. This finding provides good reason to continue the control programme until cats are finally eradicated from Marion Island.

\section{Introduction}

Marion Island $\left(46^{\circ} 55^{\prime} \mathrm{S} 37^{\circ} 45^{\prime} \mathrm{E}\right.$, surface area $\left.290 \mathrm{~km}^{2}\right)$ lies in the subantarctic Indian Ocean. It has been the subject of much biological research over the last few decades (e.g. Smith 1987, Cooper and Brown in press) and has been identified as a relatively undisturbed island worthy of a high degree of environmental protection (Cooper and Condy 1988, Cooper and Berruti 1989). The greatest current threat to the natural biota of the island is thought to be from introduced alien plants and animals (Cooper and Brooke 1986, Watkins and Cooper 1986). The alien species that has had the most obvious effect on the island's biota is the feral domestic or house cat Felis catus, which preys extensively on birds at Marion Island (van Aarde 1980, van Rensburg 1985, Bloomer and Bester 1990).

Domestic cats first became established at Marion Island as a feral population following the introduction of five animals in 1948-1949, although individual animals had previously been brought ashore from as early as 1818 or 1819 (van Aarde and Skinner 1981, Watkins and Cooper 1986). The first feral animals were seen in 1951 and soon thereafter had spread over the whole of the island below the 450 m contour (van Aarde 1979, van Aarde and Skinner 1981). By 1975 the feral population was estimated to be 2,139 \pm 290 animals (van Aarde 1979) and to have reached 3,405 in 1977 (van Aarde 1978). The viral disease feline panleucopaenia was introduced as a primary control measure in 1977 , and by 1982 the population was estimated to have been reduced to $615 \pm 107$ animals (van Rensburg et al. 1987) A secondary control measure, shooting primarily at night, 
commenced in 1986, after experimental shooting in 1981-1983 had shown its feasibility (van Rensburg and Bester 1988a, Bloomer and Bester 1990). Between August 1986 and April 1990, 952 cats were removed from the feral population by shooting and, from 1989, by gin-trapping (Bloomer and Bester in press).

The diet of feral cats at Marion Island has been assessed over the period 1975 to 1989 and found to consist largely of burrowing petrels of the family Procellariidae (van Aarde 1980, van Rensburg 1985, Bloomer and Bester 1990). One species taken is the winter-breeding Great-winged Petrel Pterodroma macroptera. In 1975 van Aarde (1980) estimated cats were killing 47,987 Great-winged Petrels annually at Marion Island. In 1982, the reduced cat population was estimated to have taken 12,951 Great-winged Petrels (van Rensburg 1985).

Great-winged Petrels are thought to be at particular risk from cats because of their winter-breeding habit, when few other burrowing petrels are present (van Aarde 1980, Cooper and Brown in press), and because of their long breeding season and relatively large burrows, which allow ready access to cats (Schramm 1983, van Rensburg and Bester 1988b). The relative rarity of Great-winged Petrels at Marion Island in comparison with cat-free Prince Edward Island (Schramm 1986), coupled with their very low breeding a success at Marion in 1979 and 1980 (Schramm 1983), led to the species's inclusion as nationally threatened in the South African Red Data Book for birds with the category of Vulnerable (Brooke 1984).

In order to ascertain whether the reduced cat population was still having an adverse affect on burrowing petrels, the breeding success of the Great-winged Petrel was assessed during the austral winter of 1990.

\section{Methods}

During the period 14 June to 6 July 1990, 50 burrows of the Great-winged Petrel were located and marked by A.F. with numbered bamboo poles among Blechnum pennamarina fern slopes in the Van den Boogaard River valley and Nellie Humps. Burrows were provided with removable earth plugs lined with hessian sacking, as described by Sinclair (1981) and Schramm (1983). Observations of nest contents were made at one- to two-weekly intervals until all surviving chicks had fledged. A record was kept of the number of eggs that hatched and failed burrows were examined for signs of predation by cats.

\section{Results}

Of the 50 nests, all contained adult birds, but eggs were present in only 47 on excavation. Twenty-eight eggs (59.6\%) hatched between 14 July and 12 August. All 28 chicks fledged between 15 October and 29 November, giving a fledging success of $100 \%$, and an overall breeding success of $59.6 \%(n=47)$. Because egg laying by the Great-winged Petrel at Marion Island is completed by 10 June (Newton and Fugler 1989), hatching and breeding success figures may be overestimates due to the possibility that some early egg failures were missed. If it is assumed that the three occupied burrows found without eggs had failed prior to excavation, then a breeding success of $56.0 \%$ pertains. No signs of cat pre- 
dation (e.g. tooth marks on egg shells, partially eaten chick or adult corpses) were seen.

\section{Discussion}

In 1979 and 1980 the breeding success of the Great-winged Petrel at Marion Island was nil in both years ( $n=17$ and 40 nests studied) (Schramm 1983). In 1982 breeding success was $20.5 \%(n=53)$, but was again nil in $1984(n=35)$, primarily due to cat predation of chicks (Newton and Fugler 1989). Schramm (1983) found that $33 \%$ of 30 fresh burrows of Great-winged Petrels at nearby Prince Edward Island, which is cat-free (Watkins and Cooper 1986), contained chicks in September 1979 , whereas only $1 \%$ of 109 burrows contained chicks at Marion Island at the same time. In 1982 van Rensburg and Bester (1988b) found that Greatwinged Petrels bred significantly more successfully inside an electrified fenced cat exclosure than in an unprotected control area at Marion Island $(50 \% \mathrm{com}-$ pared with $0 \%$ of monitored burrows being occupied prior to fledging; $\mathrm{p}<0.05)$, thereby confirming the role of cats in causing low breeding success in the species.

Hatching and fledging periods in 1990 were similar to those given by Newton and Fugler (1989), suggesting that it was a "normal" year for Great-winged Petrels at Marion Island. A marked improvement in breeding success was noticeable from the earlier studies (o-20.5\% during $1979-1984$ to $59.6 \%$ in 1990). It is not thought that this large difference can be solely explained by the fact that 1990 observations did not commence prior to hatching, especially since low breeding success in the previous studies was largely due to chick mortality $100 \%$ in 1979, 1980 and 1984 (Schramm 1983, Newton and Fugler 1989), but zero in the present study. Early egg failures were likely to have been missed in 1980 and 1982 according to Newton and Fugler (1989), so the 1982 breeding success figure of $20.5 \%$ may also have been an overestimate. In 198310 chicks (28\%) were found in their burrows partially eaten by cats, and both Schramm (1983) and Newton and Fugler (1989) considered cat predation to be the cause of the low breeding success figures they obtained.

It is considered that the greatly improved breeding success, with zero chick mortality, of the Great-winged Petrel at Marion Island observed in 1990 is a direct consequence of the ongoing cat control programme. This finding provides good reason for the continuation of the control programme until feral cats are finally eradicated from Marion Island. The breeding success of summer-breeding burrowing petrels at Marion Island should now be measured in a similar manner in order to ascertain whether their populations may also be on the road to recovery.

\section{Acknowledgements}

Research at Marion Island forms part of the South African National Antarctic Research Programme and is funded financially and logistically by the South African Department of Environment Affairs. We acknowledge the important research conducted by past and present members of the Mammal Research Institute, University of Pretoria, on the feral 
cats of Marion Island. Thanks are due to members of the Marion 47 Team for help in the field and M. N. Bester, J. P. Bloomer, R. J. van Aarde and P. J. J. van Rensburg for comments on a draft manuscript.

\section{References}

van Aarde, R. J. (1978) Reproduction and population ecology in the feral house cat Felis catus on Marion Island. Carniv. Genet. Newsl. 3: 288-316.

van Aarde, R. J. (1979) Distribution and density of the feral house cat Felis catus on Marion Island. S. Afr. J. Antarct. Res. 9: 14-19.

van Aarde, R. J. (1980) The diet and feeding behaviour of feral cats, Felis catus at Marion Island. S. Afr. J. Wildl. Res. 10: 123-128.

van Aarde, R. J. and Skinner, J. D. (1981) The feral cat population at Marion Island: characteristics, colonization and control. Comm. Nat. Franc. Rech. Antarct. 51: 281-288.

Bloomer, J. P. and Bester, M. N. (1990) Diet of a declining feral cat Felis catus population on Marion Island. S. Afr. Wildl. Res. 20: 1-4.

Bloomer, J. P. and Bester, M. N. (in press) Control of feral cats on Marion Island. Biol. Conserv.

Brooke, R. K. (1984) South African Red Data Book: birds. S. Afr. Nat. Sci. Prog. Rpt 97: 1-213.

Cooper, J. and Berruti, A. (1989) The conservation status of South Africa's continental and oceanic islands. Pp. $239-253$ in B. J. Huntley, ed. Biotic diversity in southern Africa: concepts and conservation. Cape Town: Oxford University Press.

Cooper, J. and Brooke R. K. (1986) Alien plants and animals on South African continental and oceanic islands: species richness, ecological impacts and management. Pp. 133-142 in I. A. W. Macdonald, F. J. Kruger and A. A. Ferrar, eds. The ecology and management of biological invasions in southern Africa. Cape Town: Oxford University Press.

Cooper, J. and Brown, C. R. (in press) Ornithological research at the Prince Edward Islands: a review of achievements. S. Afr. J. Antarct. Res. 20.

Cooper, J. and Condy, P. R. (1988) Environmental conservation at the subantarctic Prince Edward Islands: a review and recommendations. Environ. Conserv. 15: 317-326.

Newton, I. P. and Fugler, S. R. (1989) Notes on the winter-breeding Great-winged Petrel Pterodroma macroptera and Grey Petrel Procellaria cinerea at Marion Island. Cormorant 17: 27-34.

van Rensburg, P. J. J. (1985) The feeding ecology of a decreasing feral House Cat, Felis catus, population at Marion Island. Pp. 620-624 in W. R. Siegried, P. R. Condy and R. M. Laws, eds. Antarctic nutrient cycles and food webs. Berlin: Springer-Verlag.

van Rensburg, P. J. J. and Bester, M. N. (1988a) Experiments in feral cat population reduction by hunting on Marion Island. S. Afr. J. Wildl. Res. 18: 47-50.

van Rensburg, P. J. J. and Bester, M. N. (1988b) The effect of cat Felis catus predation on three breeding Procellariidae species on Marion Island. S. Afr. J. Zool. 23: 301-305.

van Rensburg, P. J. J., Skinner, J. D. and van Aarde, R. J. (1987) Effects of feline panleucopaenia on the population characteristics of feral cats on Marion Island. J. Appl. Ecol. 24: 63-73.

Schramm, M. (1983) The breeding biologies of the petrels Pterodroma macroptera, $P$. brevirostris and $P$. mollis at Marion Island. Emu 83: 75-81.

Schramm, M. (1986) Burrow densities and nest site preferences of petrels (Procellariidae) at the Prince Edward Islands. Polar Biol. 6: 63-70.

Sinclair, J. C. (1981) Techniques for observing Subantarctic petrels at the nest. Cormorant 9: $67-72$.

Smith, V. R. (1987) The environment and biota of Marion Island. S. Afr. J. Sci. 83: 211-220. 
Watkins, B. P. and Cooper, J. (1986) Introduction, present status and control of alien species at the Prince Edward Islands, sub-Antarctic. S. Afr. J. Antarct. Res. 16: 86-94.

JOHN COOPER and ANDRÉ FOURIE

Percy FitzPatrick Institute of African Ornithology, University of Cape Town, Rondebosch 7700, South Africa. 